\title{
MENTAL DISORDERS FOLLOWING COVID-19 INFECTION: A SYSTEMATIC REVIEW OF ACUTE AND LONG-TERM PSYCHIATRIC MANIFESTATIONS AND ASSOCIATED BRAIN CHANGES
}

\author{
Paale Ruben Fischer ${ }^{1}$ and Lubova Renemane ${ }^{2,3}$ \\ ${ }^{1}$ Rīga Stradiṇš University, 16 Dzirciema Str., Rīga, LV-1007, LATVIA, \\ paalefischer@yahoo.de \\ ${ }^{2}$ Faculty of Medicine, Rīga Stradiṇš University, 2 Tvaika Str., Rīga, LV-1005, LATVIA, \\ lubova.renemane@rsu.Iv \\ ${ }^{3}$ Via Una Clinic, 10 Katrīnas Dambis, LV-1045, Rīga, LATVIA \\ \# Corresponding author Lubova Renemane
}

Communicated by Guna Laganovska

\begin{abstract}
The severe acute respiratory syndrome coronavirus 2 (SARS-CoV-2) primarily affects the respiratory tract, but sometimes also other organs, including the central nervous system (CNS). It is not well understood how the virus affects the CNS and how frequently it happens. Our review provides insight into the occurrence of mental disorders in Corona Virus Disease 2019 (COVID-19) patients. We also collected information about the biological basis of the susceptibility of brain cells to SARS-CoV-2 and its implication to psychiatric manifestations. We included 24 publications in our review, reporting psychiatric manifestations published between 31 December 2019 and 30 July 2020, using the Preferred Reporting Items for Systemic Review and Meta-Analysis statement. Mental disorders occurred in up to one-fifth of patients during the acute phase of the infection. The most common disorders included anxiety-related disorders, mood-spectrum disorders, impaired consciousness, confusion, delirium and psychosis. The onset of psychiatric manifestations is not always preceded by respiratory symptoms, but occurs initially in COVID-19 patients. Long-term manifestations are mainly depression and post-traumatic stress symptoms. The obtained data allow the statement that direct infection of the CNS by SARS-CoV-2 could be responsible for the observed findings. To further investigate long-term psychiatric manifestations, randomised controlled studies must be initiated.
\end{abstract}

Key words: mental disorders, psychiatry, brain changes, Covid-19, susceptibility, SARS-CoV-2.

\section{INTRODUCTION}

Since the beginning of the $21^{\text {st }}$ century, an animal betacoronavirus underwent a successful crossover to humans three times, causing severe respiratory diseases. The first event took place in China in 2002, when an acute severe respiratory disease was seen in people without known cause. Later, this coronavirus was named Severe Acute Respiratory Syndrome Coronavirus (SARS-CoV). The second outbreak took place in 2012 in Saudi-Arabia, showing almost identical symptoms, but the responsible agent was only related to SARS-CoV and therefore named Middle Eastern Respiratory Syndrome Coronavirus (MERS-CoV) (Singhal, 2020). In December 2019, the third event took place in Wuhan, China and the virus was named Severe Acute Respiratory Syndrome Coronavirus-2 (SARSCoV-2), causing the Coronavirus Disease 2019 (COVID19) (Fu et al., 2020). SARS-CoV-2 is closely related to SARS-CoV and utilises the same cellular receptor, angiotensin-converting enzyme 2 (ACE2) for cell entry. The cellular co-factor needed for cell entry is transmembrane protease serine 2 (TMPRSS2), which facilitates SARS-CoV-2 spike protein priming (Heurich et al., 2014; Hoffmann et al., 2020). The most common symptoms of COVID-19 patients include fever, cough, fatigue, headache, sore throat, myalgia and dyspnea. A subset of COVID-19 patients also manifest severe pneumonia, leading to respiratory failure and death (Fu et al., 2020; Singhal, 2020). How- 
ever, complications of COVID-19 are not limited to the respiratory system. There are reports of a wide variety of extrapulmonary and systemic manifestations, including gastrointestinal symptoms, renal failure, liver damage, cardiac injury, sepsis and shock, often leading to fatal outcome. In addition, involvement of the central nervous system (CNS) has been reported, thought to be mediated by either direct neuronal damage through SARS-CoV-2 or by host immunemediated damage due to pathogenic levels of inflammatory mediators (Alam et al., 2020; Zaim et al., 2020). There are publications addressing direct neurological manifestations in COVID-19 patients, such as taste and smell disorders and headache (Chen et al., 2020; Leonardi et al., 2020; Zubair et al., 2020). Other publications are addressing the indirect psychological impact of the pandemic (e.g., due to social restrictions) on the general population (Amerio et al., 2020; Loades et al., 2020; Pfefferbaum and North, 2020; Rajkumar, 2020). Interestingly, we could identify only two systematic reviews on the direct impact of COVID-19 infection on the mental state and the occurrence of psychiatric symptoms. One review included 12 publications (Rogers et al., 2020) and the second review included only two articles the reported psychiatric symptoms in COVID-19 patients (Vindegaard and Benros, 2020).

In October 2020, more than 41500000 cases of COVID-19 were registered worldwide. Also, Latvia is currently in midstream of the 'second wave' and new registered cases increase day by day (Anonymous, 2020). Hence, it is important to investigate the potential impact of COVID-19 on the mental state of infected patients. The aim of this systematic review is to provide evidence of occurrence of mental disorders as a direct result of COVID-19. These include psychiatric symptoms occurring during the acute phase of illness, as well as after resolved infection. In addition, we want to hypothesise about potential psychiatric long-term outcomes in patients who survived COVID-19. Furthermore, we want to investigate the susceptibility of the CNS, when it comes to the infection with SARS-CoV-2 and structural changes of the CNS, which are associated with COVID-19.

\section{LITERATURE RESEARCH STRATEGY}

This systematic review made use of the PRISMA statement in concomitance with the flow diagram, to depict the flow of information throughout the review. However, there was no registered study protocol (Liberati et al., 2009).

PubMed, the preprint servers medRxiv and bioRxiv were screened systematically for related articles, published between the 31 December 2019 and 30 July 2020. The following key words and Boolean operators were applied for the search inquiry: 'Covid-19' OR 'sars-cov-2' OR '2019-ncov' AND 'mental disorders' OR 'mental health' OR 'clinic' OR 'depression' OR 'delirium' OR 'hallucinations' OR 'anxiety' OR 'cognitive dysfunction' OR 'psychotic disorder' OR 'CNS' OR 'neurology' OR 'brain changes' OR 'brain MRI' OR 'brain CT'. One reviewer screened title, abstract, as well as full text of the retrieved articles independently but twice, to ensure that they met inclusion crite- ria. Data extraction of eligible articles was also done independently by the same investigator.

Every article, published in either English or German language and reporting the occurrence of mental disorders in patients with COVID-19 or reporting structural brain changes or susceptibility of brain areas for COVID-19 infection, was included. Exclusion criteria comprised studies, which included participants $<18$ years old, participants with diagnosed mental disorders prior to the infection with SARS-CoV-2, and participants that were not tested positive for COVID-19. In addition, articles, which did not report any psychiatric symptoms or had results indirectly related to the COVID-19 infection, were excluded. Furthermore, we excluded articles, which had no freely accessible full text or were not original research.

Characteristics of research studies. We identified 6669 articles through the initial database search. 3071 articles were from PubMed, 2820 from the medRxiv preprint server and 778 from the bioRxiv preprint server. After removal of duplicates via EndNote X9, 6657 articles underwent quantitative screening, from which 6519 articles were excluded after screening of title and abstract. 138 articles were assessed for eligibility, from which 114 articles were excluded on the base of the exclusion criteria. Twenty-four articles were included in the qualitative synthesis. The PRISMA flow diagram is shown in Figure 1. The characteristics of the included studies are presented in Tables 1-3. Of the 24 studies, eight were retrospective studies, one was a crosssectional study, one was a surveillance study, one a point prevalence study, one a self-report study and one had a basic research design, and eleven were case reports or case series. Overall, 20 of 24 studies were peer-reviewed journal articles and four were published preprints.

\section{MENTAL DISORDERS DURING THE ACUTE PHASE OF COVID-19 INFECTION}

A surveillance study from the UK utilised 153 rapid reports and defined $39(31 \%)$ cases with an altered mental status. They attributed the alteration of the mental state to neuropsychiatric disorders in $23(59 \%)$ cases: psychosis (ten cases), neurocognitive disorder (six cases) and other psychiatric disorders (seven cases). Other psychiatric disorders included depression (three cases), personality change (two cases), catatonia (one case) and mania (one case) (Varatharaj et al., 2020).

A retrospective study from the UK reviewed the clinical picture of 43 patients. Of these, ten patients (mostly $>50$ years old) had an unspecified encephalopathy (parainfectious or septic encephalopathy) with delirium. One patient also manifested a psychosis, which was characterised by visual and auditory hallucinations, delusions of persecution, Capgras delusion and complex systematised delusional misperceptions, as well as aggressive behaviour (Paterson et al., 2020). Another retrospective study from Spain enrolled 16 patients with proven COVID-19 infection and new-onset 


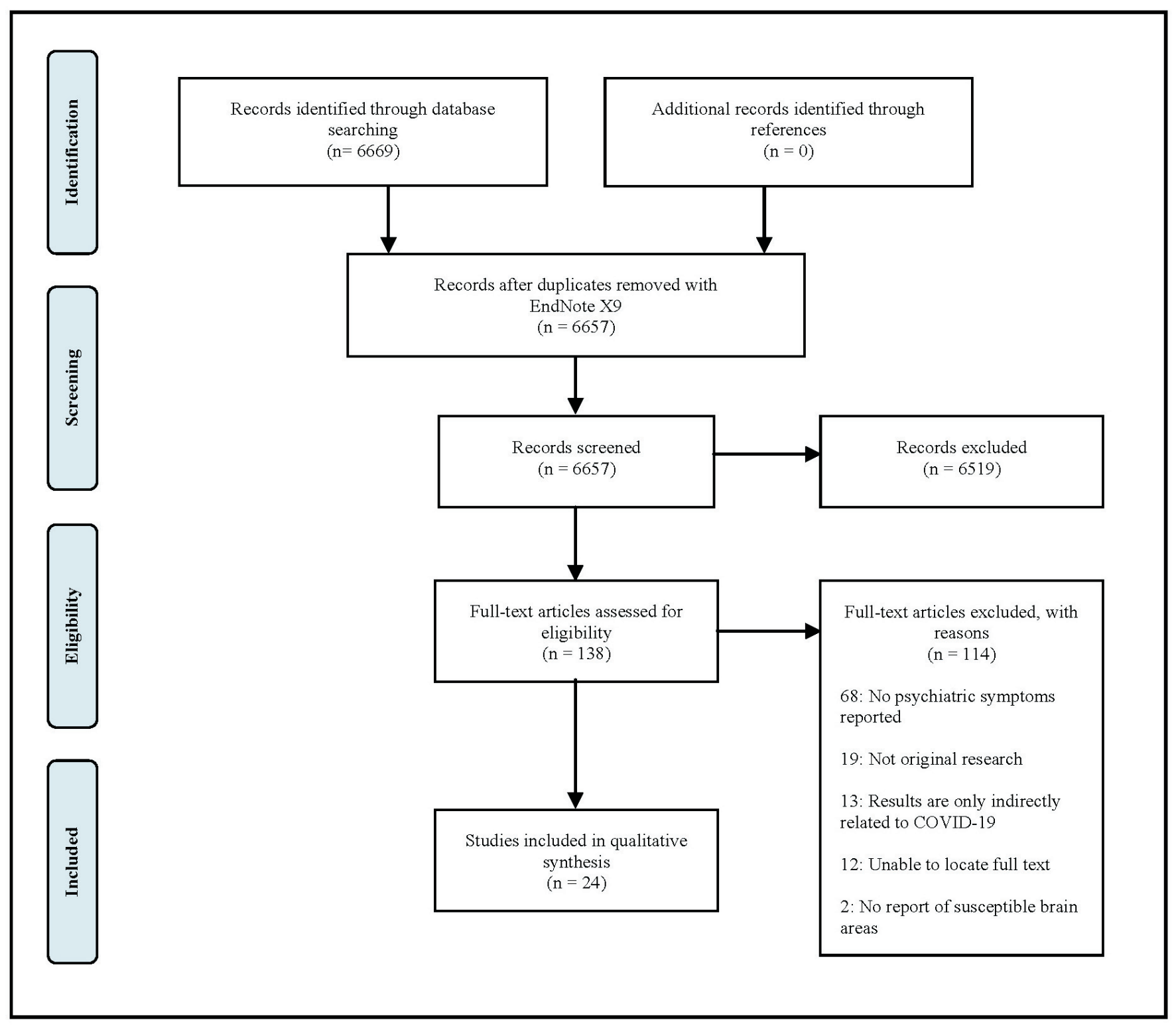

Fig. 1. PRISMA flow diagram illustrating flow of information throughout the systematic review.

psychotic symptoms. Of these 16 patients, six were diagnosed with delirium. Ten patients presented with delusions. Of these, four had auditory hallucinations and one had visual hallucinations. The most frequent types of manifested delusions were delusions of harm, as well as persecutory and referential beliefs (Parra et al., 2020).

Ferrando et al. (2020) documented the case of a 30-year old male, who presented in the emergency departement with bizarre behaviour, severe anxiety, suicidal ideation and auditory hallucinations, disorientation in himeself and showed delusions of percecution. He was then tested postive for COVID-19, despite having any abnormal chest computer tomography $(\mathrm{CT})$ findings or respiratory symptoms (Ferrando et al., 2020).

Two retrospective studies from China and one case report from Spain reported impaired consciousness in patients affected by COVID-19. Zhang et al. (2020) assessed the clini- cal characteristics of 82 deceased COVID-19 patients. They reported an unspecified consciousness problem as initial symptom in $17(20.7 \%)$ patients (Zhang et al., 2020). Huang et al. (2020) assessed 36 COVID-19 non-survivors. They reported unspecified disturbances of consciousness in eight (22.22\%) patients (Huang et al., 2020). A case report from Spain documents a 74-year old female who presented with headache, photophobia, vomiting and progressive confusion and impaired consciousness. Her nasopharyngeal polymerase chain reaction (PCR) test was positive for SARS-CoV-2, but she did not develop any respiratory symptoms or fever over her clinical course (Cebrian et al., 2020).

Overall, three retrospective studies from China and one case report from Saudi-Arabia reported confusion as a clinical finding in COVID-19 patients. Qi et al. (2020) examined 267 patients. They sub-grouped these patients into nonsevere cases (217) and severe cases (50). Overall, 25 pa- 
Table 1. Characteristics of the studies reporting mental disorders as a direct result of COVID-19 in acute phase of infection

\begin{tabular}{|c|c|c|}
\hline $\begin{array}{c}\text { Author } \\
\text { (All published } \\
\text { in 2020) }\end{array}$ & $\begin{array}{l}\text { Country of origin / type } \\
\text { of study / sample size, } n\end{array}$ & $\begin{array}{l}\text { Mental disorders, } \\
\text { number of cases }(\%)\end{array}$ \\
\hline Nalleballe et al. & $\begin{array}{l}\text { USA / } \\
\text { Retrospective study / } \\
40469\end{array}$ & $\begin{array}{l}\text { Psychiatric manifestations } \\
\text { in } 5193 \text { cases }(12.8 \%) \text { : } \\
\text { - Anxiety and related dis- } \\
\text { orders: } 1869(4,6 \%) \\
\text { - Mood disorders: } 1549 \\
(3.8 \%) \\
\text { - Sleep disorders: } 1394 \\
(3.4 \%) \\
\text { - Emotional state symp- } \\
\text { toms: } 318 \text { (0.8\%) } \\
\text { - Suicidal ideation: } 63 \\
(0.2 \%)\end{array}$ \\
\hline Parra et al. & $\begin{array}{l}\text { Spain / Retrospective } \\
\text { study / } 16\end{array}$ & $\begin{array}{l}\text { Psychosis in } 10 \text { cases } \\
(62.5 \%)\end{array}$ \\
\hline Majadas et al. & Spain / Case report / 1 & Psychosis \\
\hline Ferrando et al. & USA / Case report / 1 & Psychosis \\
\hline Varatharaj et al. & $\begin{array}{l}\text { UK / } \\
\text { Surveillance study / } \\
153\end{array}$ & $\begin{array}{l}\text { Neuropsychiatric disorders } \\
\text { in } 23 \text { cases: } \\
\text { - Psychosis: } 10(43.5 \%) \\
\text { - Neurocognitive disorder: } \\
6(26.1 \%) \\
\text { - Other psychiatric disor- } \\
\text { ders: } 7(30.4 \%) \text { : } \\
\text { depression: } 3(42.8 \%) \text {; } \\
\text { personality change: } 2 \\
(28.6 \%) \text {; catatonia: } 1 \\
(14.3 \%) \text {; mania: } 1(14.3 \%)\end{array}$ \\
\hline Paterson et al. & \multicolumn{2}{|c|}{$\begin{array}{l}\text { UK / Retrospective study / Delirium: } 10 \text { (23.2\%) } \\
43\end{array}$} \\
\hline Hosseini et al. & UK / Case series / 2 & Delirium \\
\hline Soysal and Kara & Turkey / Case report / 1 & Delirium \\
\hline Zhang et al. & $\begin{array}{l}\text { China / Retrospective } \\
\text { study / } 82\end{array}$ & $\begin{array}{l}\text { Impaired consciousness: } \\
17(20.7 \%)\end{array}$ \\
\hline Huang et al. & $\begin{array}{l}\text { China / Retrospective } \\
\text { study / } 36\end{array}$ & $\begin{array}{l}\text { Impaired consciousness: } 8 \\
(22.2 \%)\end{array}$ \\
\hline Cebrian et al. & Spain / Case report / 1 & Impaired consciousness \\
\hline Qi et al. & $\begin{array}{l}\text { China / Retrospective } \\
\text { study / } 267\end{array}$ & Confusion: 25 (9.3\%) \\
\hline Chen et al. & $\begin{array}{l}\text { China / Retrospective } \\
\text { study / } 99\end{array}$ & Confusion: 9 (9.1\%) \\
\hline Leung et al. & $\begin{array}{l}\text { China /Retrospective } \\
\text { study / } 50\end{array}$ & Confusion in $1(2 \%)$ \\
\hline Alkeridy et al. & $\begin{array}{l}\text { Saudi Arabia / Case report } \\
\text { / } 1\end{array}$ & t Confusion \\
\hline Bo et al. & $\begin{array}{l}\text { China / Self-report study / } \\
714\end{array}$ & $\begin{array}{l}\text { Posttraumatic stress symp- } \\
\text { toms: } 687(96.2 \%)\end{array}$ \\
\hline Epstein et al. & Israel / Case report / 1 & $\begin{array}{l}\text { Anxiety and suicide at- } \\
\text { tempt }\end{array}$ \\
\hline Mawhinney et al. & UK / Case report / 1 & Acute mania \\
\hline
\end{tabular}

COVID-19, corona virus disease 2019

tients $(9.4 \%)$ had confusion. Of those 25 patients, $15(6.9 \%)$ were non-severe cases and 10 (20\%) were severe cases (Qi et al., 2020). Leung et al. (2020) reported clinical characteristics and outcomes of 50 patients. One patient (2\%) had noted confusion during the clinical course (Leung et al., 2020). Chen et al. (2020) described the clinical characteristics of 99 patients affected by COVID-19. Of them, 9 (9\%) had confusion. Fifty patients suffered from chronic medical illnesses prior to the COVID-19 infection (Chen et al., 2020). Alkeridy et al. (2020) reported the case of a 73-year old male with acute confusion at his home. Later in the emergency department he was conscious and alert, but showed difficulties in orientation towards other people. After 24 hours he developed a fever and a positive PCR for SARS-CoV-2 (Alkeridy et al., 2020).

We reviewed three articles, one from the UK, one from Spain and one from Turkey, comprising four patients with delirium during the acute phase of COVID-19. The case series from the UK reported two patients, both showing atypical symptoms in the setting of an acute COVID-19 infection. One report documents a 46-year old male with acute hypoactive delirium, disinhibition and confusion, all preceded by a two-day history of headache. Later he developed some neurological manifestations and cognitive disturbances, including impaired verbal fluency, phrase repletion and delayed recall. The second report documents a 79-year old female who was admitted to the hospital due to a seizure, which was preceded a few hours earlier by confusion and difficulties in communication. She had two generalised seizures, 60 hours after admission, followed by a state of delirium (Hosseini et al., 2020). The case report from Spain documents a 63-year old man with a positive COVID-19 PCR, who presented with delirium during hospitalisation. After the delirium had improved adjacent to the respiratory symptoms, bizarre delusions and incoherent speech and thoughts persisted. During this period, he still was PCRpositive, but did not show respiratory symptoms of any form (Majadas et al., 2020). One case report from Turkey documents a 70-year-old male, who had cognitive and perception problems, together with disturbances of memory and orientation. He underwent chest computed tomography (CT) and PCR testing, which both indicated a COVID-19 infection, even though not having any fever, dry cough, or chest distress. The condition was diagnosed as delirium (Soysal and Kara, 2020).

Bo et al. (2020) conducted an online-based study using the self-reported Posttraumatic Stress Disorder ChecklistCivilian Version, which assessed 714 stable COVID-19 patients prior to their discharge. The study showed a prevalence of significant posttraumatic stress symptoms associated with COVID-19 in 687 cases (95\% CI, 94.8-97.6\%) (Bo et al., 2020). One retrospective study from the US analysed the clinical manifestations of 40469 adult COVID-19 patients via an electronic medical record database. Of these, $5193(12.8 \%)$ patients had psychiatric manifestations. Among the most common psychiatric manifestations were anxiety and other related disorders in 1869 (4.6\%) patients, followed by mood disorders in 1549 (3.8\%) patients, and sleep disorders in 1394 (3.4\%) patients. Less common 
Table 2. Characteristics of the studies reporting mental disorders as long-term manifestation in COVID-19 survivors

\begin{tabular}{|c|c|c|c|c|}
\hline Author & $\begin{array}{l}\text { Country } \\
\text { of origin }\end{array}$ & Type of study & $\begin{array}{l}\text { Sample } \\
\text { size (n) }\end{array}$ & Reported mental disorders occurring in COVID-19 survivors \\
\hline Zhang et al. (2020) & China & Cross-sectional study & 57 & $\begin{array}{l}\text { Increased prevalence of depression in patients who experienced } \\
\text { COVID-19; } \\
29.2 \%(p=0,016) \text { in comparison to } 9.8 \% \text { in the individuals under } \\
\text { quarantine without COVID-19 }\end{array}$ \\
\hline McLoughlin et al. (2020) & UK & Point prevalence study & 71 & $\begin{array}{l}\text { No significant impact on mean cognitive score in patients who had } \\
\text { COVID- } 19 \text { with or without delirium; } \\
34.5 \text { and } 41.5 \text { out of } 53 \text {, respectively }(p=0.06)\end{array}$ \\
\hline Lim et al. (2020) & UK & Case report & 1 & $\begin{array}{l}\text { Persistent psychotic disorder during } 52 \text { days after initial hospital } \\
\text { admission due to COVID-19 }\end{array}$ \\
\hline
\end{tabular}

COVID-19, corona virus disease 2019

Table 3. Characteristics of the studies reporting susceptibility of the human brain to SARS-CoV-2 and structural brain changes in COVID-19 patients

\begin{tabular}{|c|c|c|}
\hline Author & $\begin{array}{c}\text { Country of origin / } \\
\text { type of study / sam- } \\
\text { ple size (n) }\end{array}$ & $\begin{array}{c}\text { Reported susceptible brain areas to } \\
\text { SARS-CoV-2 and associated struc- } \\
\text { tural brain changes }\end{array}$ \\
\hline $\begin{array}{l}\text { Nampoothiri et } \\
\text { al. (2020) }\end{array}$ & $\begin{array}{l}\text { France / basic } \\
\text { research / not } \\
\text { applicable }\end{array}$ & $\begin{array}{l}\text { - High levels of expressed } \\
\text { ACE2/TMPRSS2 in paraventricular } \\
\text { hypothalamic nucleus and multiple } \\
\text { brain-stem nuclei } \\
\text { - Detection of ACE2/TMPRSS2 pro- } \\
\text { teins in olfactory bulb in brain of } \\
\text { COVID-19 patient and presence of } \\
\text { SARS-Cov-2 spike protein in olfac- } \\
\text { tory nerve } \\
\text { - Viral replication in hypothalamus, } \\
\text { median eminence and arcuate nu- } \\
\text { cleus }\end{array}$ \\
\hline $\begin{array}{l}\text { Anzalone et al. } \\
(2020)\end{array}$ & $\begin{array}{l}\text { Italy / case series / } \\
4\end{array}$ & $\begin{array}{l}\text { Multifocal involvement of the cortex } \\
\text { in MRI } \\
\text { - Hyperintense areas } \\
\text { (T2-weighted/FLAIR) in parietal, } \\
\text { frontal and occipital brain regions }\end{array}$ \\
\hline $\begin{array}{l}\text { Pascual-Goni et } \\
\text { al. }(2020)\end{array}$ & $\begin{array}{l}\text { Spain / case series / } \\
2\end{array}$ & $\begin{array}{l}\text { Multiple hyperintense areas (FLAIR) } \\
\text { in MRI } \\
\text { - In pontine tegmentum, mamillary } \\
\text { bodies, cranial nerve nuclei, hypo- } \\
\text { thalamus }\end{array}$ \\
\hline
\end{tabular}

ACE2/TMPRSS2, angiotensin-converting enzyme 2/transmembrane protease serine 2; MRI, magnetic resonance imaging; T2-weighted/ FLAIR, Fluid-attenuated inversion recovery; SARS-CoV-2, severe acute respiratory syndrome coronavirus 2; COVID-19, corona virus disease 2019.

manifestations included emotional state symptoms and signs in $318(0.8 \%)$ patients and suicidal ideation in 63 $(0.2 \%)$ patients (Nalleballe et al., 2020). Additionally, two case reports, one from the UK and one from Israel, reported unique psychiatric manifestations in COVID-19 patients. Mawhinney et al. (2020) documented the case of a 41-year old male with an acute manic episode. The symptoms were preceded by one day of severe occipito-parietal headache and ten days of respiratory symptoms (Mawhinney et al., 2020). Epstein et al. (2020) presented the case of a 34-year old male who was admitted to the hospital due to a four-day history of weakness, fever and cough. The patient was transferred to an isolation ward, where anxiety and insomnia appeared. One week after his admission, he attempted suicide by jumping out of the third-floor ward (Epstein et al., 2020).

\section{MENTAL DISORDERS MANIFESTING LONG-TERM IN COVID-19 SURVIVORS}

A cross-sectional study from China assessed the characteristics of psychological distress affected by the pandemic. They obtained their data via an app-based anonymous questionnaire. The populations included in the study were individuals who freshly recovered from COVID-19 (57), individuals under quarantine (50) and individuals from the public (98). Zhang et al. (2020) reported that the patients who recovered from COVID-19 had a prevalence of $29.2 \%$ for depression, in comparison to $9.8 \%$ in individuals under quarantine $(p=0.016)$. Also, the amount of severe depressive symptoms was highest in the individuals experiencing COVID-19 infection with $19.3 \%$, in comparison to $4 \%$ in individuals under quarantine $(p=0.002)$. The prevalence of anxiety did not significantly differ between the populations. The prevalence of depression, comorbid with anxiety, was increased in two populations: in individuals who experienced COVID-19 $(21.1 \%)$ and in individuals of the general public $(22.4 \%)$, in comparison to $8 \%$ in the individuals under quarantine $(p=0,086)$ (Zhang et al., 2020). McLoughlin et al. (2020) conducted a point-prevalence study. They included every inpatient of an University College Hospital with COVID-19 and assessed them for delirium at one point in time. Overall they included 71 patients, from whom 31 had delirium and 16 did not. Four weeks after the ascertainment of delirium, cognitive function was assesed via modified Telephone Interview for Cognitive Status. The test showed similar results for patients with and without delirium. Scores were 34.5 and 41.5 of 53, respectively $(p=0,06)$ (McLoughlin et al., 2020). Additionally, a case report from the UK documents persisting psychiatric symptoms after recovery of COVID-19 infection. They reported the case of a 55-year old woman who was admitted to the hospital after a two-week history of respiratory symptoms. After discharge from the hospital she experienced confusion, auditory hallucinations, anxiety, feelings of ambivalent mood and anxiety, as well as a Capgras-like delusion, disorientation and had cognitive impairment (Lim et al., 2020). 
SUSCEPTIBILITY OF BRAIN AREAS TO SARS-COV-2 AND ASSOCIATED STRUCTURAL CHANGES

Susceptibility of brain areas to SARS-CoV-2. Nampoothiri et al. (2020) made use of the Allen Human Brain Atlas (AHBA) to investigate the susceptibility of the hypothalamus and related regions for SARS-CoV-2. They analysed the expression patterns of angiotensin-converting enzyme 2 (ACE2) and of the transmembrane protease serine 2 (TMPRSS2). Their results showed that expression of ACE2 was low in cerebral and cerebellar cortex, but high in the paraventricular hypothalamic nucleus (PVH), as well as the choroid plexus. TMPRSS2 is expressed in all studied areas and generally more abundant than ACE2. A high level of both ACE2 and TMPRSS2 was found in the PVH and in multiple brain-stem nuclei, marking them as the potentially preferred port of entry and target site for SARS-CoV-2. An additional aim of the study was to find other host genes potentially involved in the SARS-CoV-2 pathogenesis, which were correlated to ACE2 and TMPRSS2. They made use of the KEGG pathway database and found several genes involved in molecular pathways and networks, which were correlated to ACE2 and TMPRSS2. The pathways yielding the most genes associated to ACE2 and TMPRSS2 were both expressed in the hypothalamus, one being marked for "olfactory transduction". In order to put these theoretical findings into context with SARS-CoV-2, they investigated the brain of a 63-year old obese male COVID-19 positive patient, who had died of severe respiratory distress and multi-organ failure after 33 days in the intensive care unit. They detected ACE2 protein around his blood vessels, and ACE2- and TMPRSS2-proteins in the outer layer of the olfactory bulb by immuno-labelling. Interestingly, this was not the case in a control brain of 36-year old obese male who was negative for SARS-CoV-2. They showed that this outer layer consisted of fibres from olfactory sensory neurons, and hence was the part where the olfactory nerve entered the olfactory bulb. Immunolabelling of the COVID-19 positive brain also showed the presence of SARS-CoV-2 spike-protein within these nerve fibres, as well as the presence of viral double-stranded RNA in numerous cells bordering the outer layer. In addition, ACE2 was expressed in the choroid plexus of the COVID-19 patient, and viral nucleocapsid protein was detected in blood vessels in the same area. COVID-19 virus replication could be demonstrated in the hypothalamus, the median eminence (ME) and arcuate nucleus (ARH) of the COVID-19 patient, due to presence of nucleocapsid protein and double-stranded RNA (Nampoothiri et al., 2020).

SARS-CoV-2-associated brain changes. Two case series, one from Italy and one from Spain, reported structural brain alteration in patients infected with COVID-19. The study from Italy comprised four patients who manifested with subacute encephalopathy. All four patients were ventilated after the onset of acute respiratory distress syndrome. After discontinuation of intubation, neurological symptoms including agitation and spatial disorientation developed. Magnetic resonance imaging (MRI) showed multifocal involve- ment of the cortex in all patients. The observed lesions had unusual characteristics, but showed consistent patterns in the patients with similar neurological symptoms. T2weighted/ Fluid-attenuated inversion recovery (FLAIR) images of all patients showed numerous hyperintense areas, appearing in the parietal, occipital and frontal regions of the brain. A few of these lesions embraced the adjacent subcortical white matter. After one month, a follow-up MRI was performed for one of the four patients, which showed entire resolution of the lesions (Anzalone et al., 2020). The case series from Spain included two patients with COVID-19 infection. The first patient was a 60 -year old female who presented with diplopia and right hemicranial headache after a 10-day history of fever, cough, hyposmia and nausea. Neurological examination showed right abducens nerve palsy and chest X-ray revealed bilateral pneumonia. Cerebrospinal fluid was negative for SARS-CoV-2 RNA. Brain MRI (FLAIR) showed hyperintensity (HI) in the pontine tegmentum, as well as localised $\mathrm{HI}$ in the right cranial nerve nuclei (VI). Hypothalamus and mammillary bodies were hyperintense as well. The pituitary gland was enlarged, and the upper pituitary stalk appeared globular.

The second patient had a history of bulimia and vomiting. Later in the hospital, she developed diplopia and paresthesia. She improved and was discharged, however three days later she developed progressive encephalopathy. She never had any respiratory symptoms or fever. Brain MRI revealed extensive $\mathrm{HI}$ in the hypothalamus and dorsal brain stem via sagittal FLAIR. Axial FLAIR showed HI, as well as a swelling in the hypothalamus, mamillary bodies, dorsal midbrain and tectum of the midbrain. Medial temporal lobes showed slight HI. Coronal FLAIR revealed extensive HI in the periventricular region of the $3^{\text {rd }}$ ventricle, as well as in mamillary bodies. Based on the imaging she was diagnosed with Wernicke-encephalopathy, despite not having thiamine deficiency or any conditions possibly causing it (PascualGoni et al., 2020).

\section{FACTORS CONTRIBUTING TO THE MENTAL DISOR- DERS FOLLOWING COVID-19 INFECTION}

The available literature provided evidence that during the acute phase of COVID-19, 2-23\% of infected patients develop mental disorders (Fig. 2). The most common manifestations were delirium or confusion, psychosis, anxiety and mood disorders, as well as impaired consciousness. Similar psychiatric manifestations also occurred during the acute phase of disease in patients affected by severe acute respiratory syndrome (SARS) during the outbreak in the beginning of the $21^{\text {st }}$ century (Cheng et al., 2004; Rogers et al., 2020). Interestingly, Cheng et al. attributed these manifestations in the respective case series mainly to the isolation of SARS patients and in some cases to administration of corticosteroids (Cheng et al., 2004). It is well known that the administration of corticosteroids, particularly in high dose, may cause a wide variety of severe psychiatric adverse effects, ranging from anxiety and insomnia to mood disorders, delirium, psychosis and dementia (Kenna et al., 2011). We 


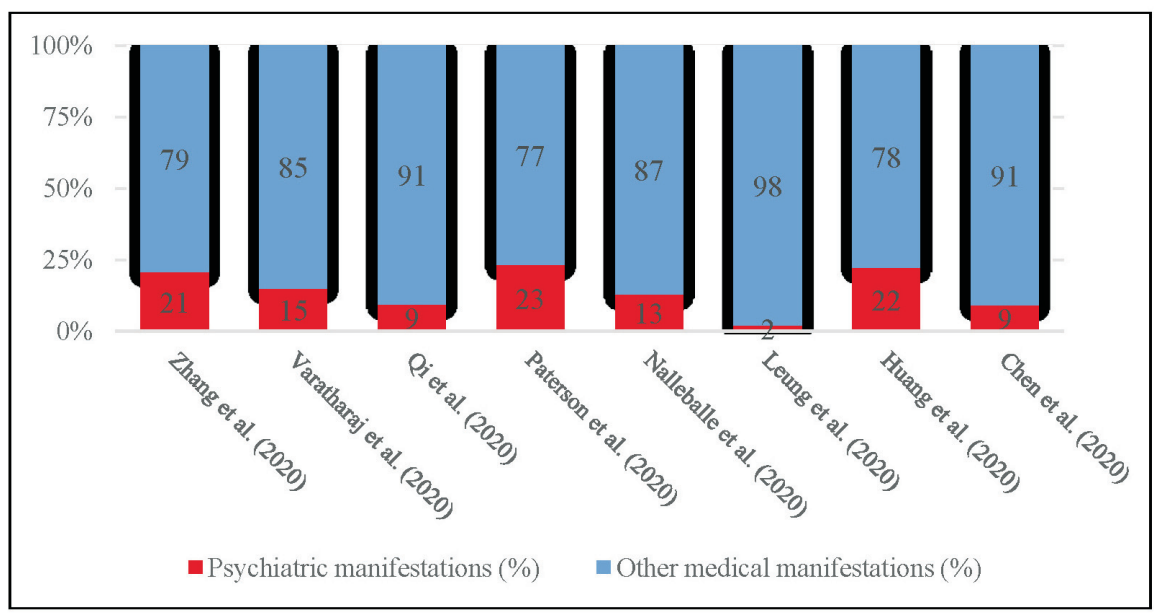

Fig. 2. Proportion of psychiatric manifestations in COVID-19 infected patients during the acute phase of disease in the studies. are excluding this potential cause in the context of the reviewed case reports and series, since only a small proportion of the included patients had received corticosteroid treatment. Furthermore, they received it only after the onset of psychiatric symptoms, and hence it had no impact on their initial manifestations. Unfortunately, we are not able to make this deduction for the reviewed descriptive studies, due to lack of detailed treatment data in most of the publications.

Other drugs widely used in the treatment and prevention of COVID-19 are chloroquine and hydroxychloroquine, despite the lack of evidence of their efficacy (Ferner and Aronson, 2020). A recent study published by Sato et al. (2020) reported psychiatric adverse effects associated with the administration of chloroquine and hydroxychloroquine. They could show an increased risk for delirium, depression, impaired consciousness and hallucinations, but no significantly increased risk for the development of psychosis, confusion, agitation and suicide in patients receiving these drugs (Sato et al., 2020). To our knowledge, two patients of our reviewed case reports were treated with hydroxychloroquine, but only after the initial onset of psychiatric symptoms.

Most of the reviewed studies dealt with hospitalised COVID-19 infected patients and did not include control groups of non-COVID-19 infected patients. Therefore, the overall frequency of mental disorders in COVID-19 patients, as published (2-23\%), is not necessarily due to the infection of the brain by SARS-CoV-2. We must consider that the hospitalisation and subsequent isolation of these patients contributes to the development of the described psychiatric manifestations. Looking at publications reporting a negative impact on the mental state of hospitalised and isolated patients, it becomes evident that adverse psychological consequences of isolation exist (Abad et al., 2010). A more recent study published by Alhajjaj et al. (2020) investigated the impact of isolation on suspected and confirmed COVID-19 patients. They observed borderline or abnormal depression and anxiety scores in $38.4 \%$ and $17.3 \%$, respectively, of isolated patients (Alhajjaj et al., 2020). In contrast, an older publication suggests that anxiety in patients with acute infections is more related to their illness and re- ferral to the hospital than to their inflicted isolation (Wilkins et al., 1988). Considering this conflicting data, we mark 'isolation' as a probable factor in the development of depression and anxiety-related disorders in COVID-19 patients, but as a less important contributor to other acute manifestations, such as delirium, psychosis or confusion. Nonetheless, one reviewed case report describing severe anxiety in an isolated COVID-19 patient, leading to a suicide attempt, can most likely be attributed to the effects of isolation (Epstein et al., 2020).

Referring to the observed rate of occurrence of mental disorders in reviewed publications, three results stand out. While most of the included studies, displayed in Figure 2, have an occurrence rate of mental disorders of 2-15\%, three publications (Huang et al., 2020; Paterson et al., 2020; Zhang et al., 2020) report a rate of $>20 \%$, increasing the overall occurrence rate to $2-23 \%$. Interestingly, the findings of these three publications comprise non-specified impaired consciousness and delirium as psychiatric manifestations. We are not able to put 'impaired consciousness' into a broader context due to lack of data in the respective publications, but we consider it as indicative for the presence of delirium.

An acute confusional state or delirium is not only a frequent cause for hospitalisation, but also a serious complication of being hospitalised. While the prevalence of delirium in the general population is only $1-2 \%$, this number rises to $14-24 \%$ in the setting of general hospital admission. The estimated incidence of delirium, which arises during the hospital stay, ranges from $6-56 \%$. This is without considering special populations, e.g. in post-operative or intensive care unit (ICU) settings. Especially in elderly patients (> 65 years of age) with co-morbidities (e.g. acute infection), the rate of delirium in an ICU setting is estimated to be as high as 80\% (Fong et al., 2009; Rai et al., 2014; Hübscher and Isenmann, 2016). Hence, without available randomised controlled studies we should be cautious linking delirium solely to COVID-19.

Availability of literature reporting the occurrence of mental disorders after resolved COVID-19 infection is still limited. Nonetheless, the reviewed literature reveals a glimpse of 
what to expect, not only immediately after a COVID-19 infection, but also in the long-term.

The available publications report an increased prevalence of 'post-traumatic stress symptoms' and 'severe depression' in COVID-19 patients after resolved infection. Similar results were observed by Ahmed et al. (2020) in the aftermath of the SARS and MERS outbreaks. They reported the occurrence of post-traumatic stress disorder (PTSD), depression and anxiety in approximately one third of survivors within the first six months following the infection. In addition, they observed only slight improvement of those patients after the six-month period (Ahmed et al., 2020). Taking into consideration that SARS-CoV-2 has certain homology to SARS-CoV and MERS-CoV (Hu et al., 2020; Rabaan et al., 2020; Yachou et al., 2020), we contemplate similar manifestations in the aftermath of COVID-19. In fact, one recently published preprint reported persistent fatigue in $52 \%$ of 128 patients who had experienced COVID-19 at 10 weeks (median) after the onset of symptoms, independently from the severity of the COVID-19 infection (Townsend et al., 2020). Moreover, one publication reported a nonsignificant impact on cognitive scores in COVID-19 patients with and without delirium at four-week follow up. What initially may seem like pleasant anticipation, should be treated with reluctance. Even if there would not be medium-term cognitive impairment in patients who had COVID-19 and delirium, we know that delirium is generally linked to cognitive impairment in the long-run and even favours the development of dementia (Davis et al., 2012; Salluh et al., 2015).

The reviewed case report describing a patient with persistent psychosis following COVID-19 infection is solitary and unique. Ultimately, it was not possible for Lim et al. (2020) to establish causation between COVID-19 and psychosis. They suggested different aetiological processes potentially responsible for the persistent psychosis, mainly raised inflammatory cytokine profile and autoimmunerelated processes after direct viral infection of the CNS (Lim et al., 2020). We found only one case report reporting a similar event. It describes a 26-year-old psychiatric naive male who had developed a psychotic state following an unspecified viral pneumonia. Unfortunately, no further information or any diagnostic markers were noted for this case (Byrne et al., 1993). The phenomenon of psychiatric disorders occurring after resolved viral infections is not entirely new, e.g., it was reported that the Spanish influenza pandemic (1918-1919) was associated with post-infectiously occurring psychosis (Menninger, 1994). Moreover, Severance et al. observed increased occurrence of schizophreniaspectrum disorders in patients during later-life, which were seropositive for a certain strain of coronavirus (HCoVNL63) (Severance et al., 2011). Based on these historical aspects, we should be vigilant about COVID-19 and similar occurrences in the long-term.

Among the reviewed publications is one report describing an acute manic episode in a COVID-19 patient and multiple reports describing the occurrence of psychoses during the acute phase of COVID-19. The patients developing these symptoms have common characteristics: most of them are young, have no medical co-morbidities and no family history of psychiatric illnesses. The available data is not sufficient to decide whether these cases are due to a direct effect of SARS-CoV-2 or if they are related to secondary mechanisms or even to psycho-social circumstances of the patients. However, evidence pointing towards infection of brain cells through SARS-CoV-2 and thereby inducing psychiatric manifestations is substantiated.

Song et al. (2020) recently published a preprint about the neuro-invasive potential of SARS-CoV-2. They were able to demonstrate direct brain infection via inoculation of SARS-CoV-2 into human brain cell organoids. In addition, they observed that direct brain infection through SARSCoV-2 is also dependent on the ACE2-receptor. Moreover, they demonstrated the presence of SARS-CoV-2 in cortical neurons of a deceased COVID-19 patient (Song et al., 2020). Beyond that, a three-month, MRI-based, follow-up study demonstrated cerebral micro-structural changes in COVID-19 patients. Significantly higher grey matter volumes in hippocampi and olfactory cortices and other structural changes could be demonstrated. Lu et al. (2020) attributed the increased grey matter volume to neurogenesis and functional compensation. Thus, they speculated that SARS-CoV-2 may use an olfactory bulb-mediated neuronal retrograde route into the CNS of these patients ( $\mathrm{Lu}$ et al., 2020). These findings support and substantiate the reviewed publications about the brain's susceptibility to SARSCoV-2 and reported structural changes (Anzalone et al., 2020; Nampoothiri et al., 2020; Pascual-Goni et al., 2020).

The findings of this study are not exhaustive and must be seen against the background that COVID-19 is a new emerging infection and disease causing a pandemic, leading to a tremendous amount of new publications in 2020. The quality of some of the included literature must be taken with reservation, because they did not go through a formal peer review process and are published online as pre-prints or are not case controlled. Moreover, the search inquiry and subsequent steps were done independently but twice by one researcher. Therefore, literature search, screening of literature, selection of eligible articles and data extraction contain a potential risk for incompleteness or could even show bias. In this review we mainly focus on the aspect of mental disorders. That is why we had to exclude publications focusing on neurological aspects of COVID-19, despite that psychiatric manifestations are often reported in association with primarily neurological symptoms in COVID-19 patients. This bears the risk that some psychiatric manifestations may be underrepresented in in the review.

\section{CONCLUSIONS}

Our systematic review gave comprehensive insight into the spectrum of mental disorders that occur during the acute phase of COVID-19. Up to one-fifth of patients may exhibit psychiatric manifestations during their clinical course. Even 
though uncommon, clinicians should also keep in mind that COVID-19 patients may present initially with psychiatric symptoms only. Regarding intermediate and long-term effects of COVID-19 on the mental state and the occurrence of psychiatric symptoms directly caused by the virus, the time frame since the onset of the pandemic is too short. Therefore, we encourage researchers to initiate controlled studies and follow-up studies with recovered patients. However, in the face of the available evidence, we anticipate a high chance of psychiatric complications in patients who survived COVID-19. Overall, our review can give valuable insight for physicians and other health care professionals who are confronted with COVID-19 patients, not only in Latvia, but also worldwide. Especially due to the second wave being currently in full swing, we hope that our provided insight can contribute to a deeper understanding of the potential manifestations that can be expected in COVID-19 patients.

\section{REFERENCES}

Abad, C., Fearday, A., Safdar, N. (2010). Adverse effects of isolation in hospitalised patients: A systematic review. J. Hosp. Infect., 76 (2), 97-102.

Ahmed, H., Patel, K., Greenwood, D. C., Halpin, S., Lewthwaite, P., Salawu, A., Eyre, L., Breen, A., O'Connor, R., Jones, A., Sivan, M. (2020). Long-term clinical outcomes in survivors of severe acute respiratory syndrome and Middle East respiratory syndrome coronavirus outbreaks after hospitalisation or ICU admission: A systematic review and meta-analysis. J. Rehabil. Med., 52 (5), jrm00063.

Alam, S. B., Willows, S., Kulka, M., Sandhu, J. K. (2020). Severe acute respiratory syndrome coronavirus-2 may be an underappreciated pathogen of the central nervous system. Eur. J. Neurol., 27 (11), 2348-2360.

Alhajjaj, A., Abduljaber, T., Alsadeq, Z., Alkhabbaz, F., Alobaidan, H., Saeed, F., Al-Jishi, J., Aljanobi, G. (2020). Psychological and mental health among isolated hospitalized suspected and confirmed COVID-19 patients, Qatif Central Hospital, Eastern Province, Saudi Arabia: A single-center descriptive study. Open J. Int. Med., 10, 245-255.

Alkeridy, W. A., Almaghlouth, I., Alrashed, R., Alayed, K., Binkhamis, K., Alsharidi, A., Liu-Ambrose, T. (2020). A unique presentation of delirium in a patient with otherwise asymptomatic COVID-19. J. Amer. Geriatr. Soc., 68 (7), 1382-1384.

Amerio, A., Aguglia, A., Odone, A., Gianfredi, V., Serafini, G., Signorelli, C., Amore, M. (2020). Covid-19 pandemic impact on mental health of vulnerable populations. Acta Biomed., 91 (9-s), 95-96.

Anonymous (2020). Worldometers.info. Available from: https://www.worldometers.info/coronavirus/ (accessed 14 October 2020).

Anzalone, N., Castellano, A., Scotti, R., Scandroglio, A. M., Filippi, M., Ciceri, F., Tresoldi, M., Falini, A. (2020). Multifocal laminar cortical brain lesions: A consistent MRI finding in neuro-COVID-19 patients. J. Neurol., 267 (10), 2806-2809.

Bo, H.-X., Li, W., Yang, Y., Wang, Y., Zhang, Q., Cheung, T., Wu, X., Xiang, Y.-T. (2020). Posttraumatic stress symptoms and attitude toward crisis mental health services among clinically stable patients with COVID-19 in China. Psychol. Med., 1-2.

Byrne, A., Zibin, T., O'Croinin, F. (1993). Viral infections and psychiatric illness. Can. J. Psychiatry, 38 (9), 631.

Cebrian, J., Gonzalez-Martinez, A., Garcia-Blanco, M. J., CeldranVivancos, D., Palacios, E. L., Reig-Rosello, G., Casado-Fernandez, L., Vivancos, J., Gago-Veiga, A. B. (2020). Headache and impaired con- sciousness level associated with SARS-CoV-2 in CSF: A case report. Neurology, 95 (6), 266-268.

Chen, N., Zhou, M., Dong, X., Qu, J., Gong, F., Han, Y., Qiu, Y., Wang, J., Liu, Y., Wei, Y., Xia, J. A., Yu, T., Zhang, X., Zhang, L. (2020). Epidemiological and clinical characteristics of 99 cases of 2019 novel coronavirus pneumonia in Wuhan, China: A descriptive study. The Lancet, 395 (10223), 507-513.

Chen, X., Laurent, S., Onur, O. A., Kleineberg, N. N., Fink, G. R., Schweitzer, F., Warnke, C. (2020). A systematic review of neurological symptoms and complications of COVID-19. J. Neurol., 1-11.

Cheng, S. K., Tsang, J. S., Ku, K. H., Wong, C. W., Ng, Y. K. (2004). Psychiatric complications in patients with severe acute respiratory syndrome (SARS) during the acute treatment phase: A series of 10 cases. Brit. J. Psychiatry, 184, 359-360.

Davis, D. H., Muniz Terrera, G., Keage, H., Rahkonen, T., Oinas, M., Matthews, F. E., Cunningham, C., Polvikoski, T., Sulkava, R., MacLullich, A. M., Brayne, C. (2012). Delirium is a strong risk factor for dementia in the oldest-old: A population-based cohort study. Brain, 135 (Pt 9), 2809-2816.

Epstein, D., Andrawis, W., Lipsky, A. M., Ziad, H. A., Matan, M. (2020). Anxiety and suicidality in a hospitalized patient with COVID-19 infection. Eur. J. Case Rep. Intern. Med., 7 (5), 001651.

Ferner, R. E., Aronson, J. K. (2020). Chloroquine and hydroxychloroquine in Covid-19. Brit. Med. J., 369, 2369, m1432.

Ferrando, S. J., Klepacz, L., Lynch, S., Tavakkoli, M., Dornbush, R., Baharani, R., Smolin, Y., Bartell, A. (2020). COVID-19 psychosis: A potential new neuropsychiatric condition triggered by novel coronavirus infection and the inflammatory response? Psychosomatics, 61 (5), 551-555.

Fong, T. G., Tulebaev, S. R., Inouye, S. K. (2009). Delirium in elderly adults: diagnosis, prevention and treatment. Nat. Rev. Neurol., 5 (4), 210-220.

Fu, L., Wang, B., Yuan, T., Chen, X., Ao, Y., Fitzpatrick, T., Li, P., Zhou, Y., Lin, Y.-F. et al. (2020). Clinical characteristics of coronavirus disease 2019 (COVID-19) in China: A systematic review and meta-analysis. J. Inf., 80 (6), 656-665.

Heurich, A., Hofmann-Winkler, H., Gierer, S., Liepold, T., Jahn, O., Pöhlmann, S. (2014). TMPRSS2 and ADAM17 cleave ACE2 differentially and only proteolysis by TMPRSS2 augments entry driven by the severe acute respiratory syndrome coronavirus spike protein. J. Virol., 88 (2), 1293-1307.

Hoffmann, M., Kleine-Weber, H., Schroeder, S., Krüger, N., Herrler, T., Erichsen, S., Schiergens, T. S., Herrler, G., Wu, N.-H., Nitsche, A., Müller, M. A., Drosten, C., Pöhlmann, S. (2020). SARS-CoV-2 cell entry depends on ACE2 and TMPRSS2 and is blocked by a clinically proven protease inhibitor. Cell, 181 (2), 271-280.e8.

Hosseini, A. A., Shetty, A. K., Sprigg, N., Auer, D. P., Constantinescu, C. S. (2020). Delirium as a presenting feature in COVID-19: Neuroinvasive infection or autoimmune encephalopathy? Brain Behav. Immun., 88, 68-70.

Hu, T., Liu, Y., Zhao, M., Zhuang, Q., Xu, L., He, Q. (2020). A comparison of COVID-19, SARS and MERS. Peer J., 8, e9725.

Huang, Y., Zhou, H., Yang, R., Xu, Y., Feng, X., Gong, P. (2020). Clinical characteristics of 36 non-survivors with COVID-19 in Wuhan, China. medRxiv, 20029009.

Hübscher, A., Isenmann, S. (2016). Delir: Konzepte, Ätiologie und klinisches Management. Fortschr. Neurol. Psychiatr., 84 (4), 233-244 (in German).

Kenna, H. A., Poon, A. W., de los Angeles, C. P., Koran, L. M. (2011). Psychiatric complications of treatment with corticosteroids: Review with case report. Psychiatry Clin. Neurosci., 65 (6), 549-560. 
Leonardi, M., Padovani, A., McArthur, J. C. (2020). Neurological manifestations associated with COVID-19: A review and a call for action. J. Neurol., 267 (6), 1573-1576.

Leung, K. S.-S., Ng, T. T.-L., Wu, A. K.-L., Yau, M. C.-Y., Lao, H.-Y., Choi, M.-P., Tam, K. K.-G., Lee, L.-K., Wong, B. K.-C., Ho, A. Y.-M. et al. (2020). A territory-wide study of early COVID-19 outbreak in Hong Kong community: A clinical, epidemiological and phylogenomic investigation. medRxiv, 20045740.

Liberati, A., Altman, D. G., Tetzlaff, J., Mulrow, C., Gøtzsche, P. C., Ioannidis, J. P. A., Clarke, M., Devereaux, P. J., Kleijnen, J., Moher, D. (2009). The PRISMA statement for reporting systematic reviews and meta-analyses of studies that evaluate healthcare interventions: explanation and elaboration. BMJ, 339 (2009), b2700.

Lim, S. T., Janaway, B., Costello, H., Trip, S. A., Price, G. (2020). Persistent psychotic symptoms following Covid-19 disease. BJ Psych. Open, 6 (5), e105.

Loades, M. E., Chatburn, E., Higson-Sweeney, N., Reynolds, S., Shafran, R., Brigden, A., Linney, C., McManus, M. N., Borwick, C., Crawley, E. (2020). Rapid systematic review: The impact of social isolation and loneliness on the mental health of children and adolescents in the context of COVID-19. J. Amer. Acad. Child Adolesc. Psychiatry., 59 (11), 1218-1239.e3.

Lu, Y., Li, X., Geng, D., Mei, N., Wu, P. Y., Huang, C. C., Jia, T., Zhao, Y., Wang, D., Xiao, A., Yin, B. (2020). Cerebral micro-structural changes in COVID-19 patients: An MRI-based 3-month follow-up study. EClin. Med., 25, 100484.

Majadas, S., Perez, J., Casado-Espada, N. M., Zambrana, A., Bullon, A., Roncero, C. (2020). Case with psychotic disorder as a clinical presentation of COVID-19. Psychiatry Clin. Neurosci., 74 (10), 551-552.

Mawhinney, J. A., Wilcock, C., Haboubi, H., Roshanzamir, S. (2020). Neurotropism of SARS-CoV-2: COVID-19 presenting with an acute manic episode. Brit. Med. J. Case Rep., 13 (6), e236123.

McLoughlin, B. C., Miles, A., Webb, T. E., Knopp, P., Eyres, C., Fabbri, A., Humphries, F., Davis, D. (2020). Functional and cognitive outcomes after COVID-19 delirium. Eur. Geriatr. Med., 11 (5), 857-862.

Menninger, K. A. (1994). Influenza and schizophrenia. An analysis of post-influenzal "dementia precox" as of 1918, and five years later further studies of the psychiatric aspects of influenza. 1926. Amer. J. Psychiatry, 151 (6 Suppl), 182-187.

Nalleballe, K., Reddy Onteddu, S., Sharma, R., Dandu, V., Brown, A., Jasti, M., Yadala, S., Veerapaneni, K., Siddamreddy, S., Avula, A., Kapoor, N., Mudassar, K., Kovvuru, S. (2020). Spectrum of neuropsychiatric manifestations in COVID-19. Brain Behav. Immun., 88, 71-74.

Nampoothiri, S., Sauve, F., Ternier, G., Fernandois, D., Coelho, C., Imbernon, M., Deligia, E., Perbet, R., Florent, V., Baroncini, M., Pasquier, F., Trottein, F., Maurage, C.-A., Mattot, V., Giacobini, P., Rasika, S., Prevot, V. (2020). The hypothalamus as a hub for SARS-CoV-2 brain infection and pathogenesis. bioRxiv, 139329.

Parra, A., Juanes, A., Losada, C. P., Alvarez-Sesmero, S., Santana, V. D., Marti, I., Urricelqui, J., Rentero, D. (2020). Psychotic symptoms in COVID-19 patients. A retrospective descriptive study. Psychiatry Res., 291, 113254 .

Pascual-Goni, E., Fortea, J., Martinez-Domeno, A., Rabella, N., Tecame, M., Gomez-Oliva, C., Querol, L., Gomez-Anson, B. (2020). COVID-19- associated ophthalmoparesis and hypothalamic involvement. Neurol. Neuroimmunol. Neuroinflamm., 7 (5),

doi: 10.1212/NXI.0000000000000823.

Paterson, R. W., Brown, R. L., Benjamin, L., Nortley, R., Wiethoff, S., Bharucha, T., Jayaseelan, D. L., Kumar, G., Raftopoulos, R. E., Zambreanu, L. et al. (2020). The emerging spectrum of COVID-19 neurol- ogy: Clinical, radiological and laboratory findings. Brain, 143 (10), 3104-3120.

Pfefferbaum, B., North, C. S. (2020). Mental health and the Covid-19 pandemic. New Engl. J. Med., 383 (6), 510-512.

Qi, D., Yan, X., Tang, X., Peng, J., Yu, Q., Feng, L., Yuan, G., Zhang, A., Chen, Y., Yuan, J. et al. (2020). Epidemiological and clinical features of 2019-nCoV acute respiratory disease cases in Chongqing municipality, China: A retrospective, descriptive, multiple-center study. medRxiv, 20029397.

Rabaan, A. A., Al-Ahmed, S. H., Haque, S., Sah, R., Tiwari, R., Malik, Y. S., Dhama, K., Yatoo, M. I., Bonilla-Aldana, D. K., Rodriguez-Morales, A. J. (2020). SARS-CoV-2, SARS-CoV, and MERS-COV: A comparative overview. Infez. Med., 28 (2), 174-184.

Rai, D., Garg, R. K., Malhotra, H. S., Verma, R., Jain, A., Tiwari, S. C., Singh, M. K. (2014). Acute confusional state/delirium: An etiological and prognostic evaluation. Ann. Indian Acad. Neurol., 17 (1), 30-34.

Rajkumar, R. P. (2020). COVID-19 and mental health: A review of the existing literature. Asian J. Psychiatr., 52, 102066.

Rogers, J. P., Chesney, E., Oliver, D., Pollak, T. A., McGuire, P., Fusar-Poli, P., Zandi, M. S., Lewis, G., David, A. S. (2020). Psychiatric and neuropsychiatric presentations associated with severe coronavirus infections: A systematic review and meta-analysis with comparison to the COVID-19 pandemic. Lancet Psychiatry, 7 (7), 611-627.

Salluh, J. I., Wang, H., Schneider, E. B., Nagaraja, N., Yenokyan, G., Damluji, A., Serafim, R. B., Stevens, R. D. (2015). Outcome of delirium in critically ill patients: Systematic review and meta-analysis. $B M J, \mathbf{3 5 0}$, h2538.

Sato, K., Mano, T., Iwata, A., Toda, T. (2020). Neuropsychiatric adverse events of chloroquine: A real-world pharmacovigilance study using the FDA Adverse Event Reporting System (FAERS) database. Biosci Trends, 14 (2), 139-143.

Severance, E. G., Dickerson, F. B., Viscidi, R. P., Bossis, I., Stallings, C. R., Origoni, A. E., Sullens, A., Yolken, R. H. (2011). Coronavirus immunoreactivity in individuals with a recent onset of psychotic symptoms. Schizophr. Bull., 37 (1), 101-107.

Singhal, T. (2020). A review of Coronavirus Disease-2019 (COVID-19). Indian J. Pediatr., 87 (4), 281-286.

Song, E., Zhang, C., Israelow, B., Lu-Culligan, A., Prado, A. V., Skriabine, S., Lu, P., Weizman, O.-E., Liu, F., Dai, Y. et al. (2020). Neuroinvasion of SARS-CoV-2 in human and mouse brain. bioRxiv, 169946.

Soysal, P., Kara, O. (2020). Delirium as the first clinical presentation of the coronavirus disease 2019 in an older adult. Psychogeriatrics, 20 (5), $763-765$.

Townsend, L., Dyer, A. H., Jones, K., Dunne, J., Kiersey, R., Gaffney, F., Connor, L., Mooney, A., Leavy, D., Ridge, K. et al. (2020). Persistent fatigue following SARS-CoV-2 infection is common and independent of severity of initial infection. medRxiv, 20164293.

Varatharaj, A., Thomas, N., Ellul, M. A., Davies, N. W. S., Pollak, T. A., Tenorio, E. L., Sultan, M., Easton, A., Breen, G., Zandi, M. et al. (2020). Neurological and neuropsychiatric complications of COVID-19 in 153 patients: A UK-wide surveillance study. Lancet Psychiatry, 7 (10), 875-882.

Vindegaard, N., Benros, M. E. (2020). COVID-19 pandemic and mental health consequences: Systematic review of the current evidence. Brain Behav. Immun., 89, 531-542.

Wilkins, E. G., Ellis, M. E., Dunbar, E. M., Gibbs, A. (1988). Does isolation of patients with infections induce mental illness? J. Infect., 17 (1), 43-47.

Yachou, Y., El Idrissi, A., Belapasov, V., Ait Benali, S. (2020). Neuroinvasion, neurotropic, and neuroinflammatory events of SARS-CoV-2: 
Understanding the neurological manifestations in COVID-19 patients. Neurol. Sci., 41, 2657-2669.

Zaim, S., Chong, J. H., Sankaranarayanan, V., Harky, A. (2020). COVID-19 and multiorgan response. Curr. Probl. Cardiol., 45 (8), 100618.

Zhang, B., Zhou, X., Qiu, Y., Song, Y., Feng, F., Feng, J., Song, Q., Jia, Q., Wang, J. (2020). Clinical characteristics of 82 cases of death from COVID-19. PLoS One, 15 (7), e0235458.

Received 17 November 2020

Accepted in the final form 27 November 2020
Zhang, J., Lu, H., Zeng, H., Zhang, S., Du, Q., Jiang, T., Du, B. (2020). The differential psychological distress of populations affected by the COVID-19 pandemic. Brain Behav. Immun., 87, 49-50.

Zubair, A. S., McAlpine, L. S., Gardin, T., Farhadian, S., Kuruvilla, D. E., Spudich, S. (2020). Neuropathogenesis and neurologic manifestations of the coronaviruses in the age of Coronavirus Disease 2019: A review. JAMA Neurol., 77 (8), 1018-1027.

\section{PSIHISKIE TRAUCĒJUMI PĒC COVID-19 INFEKCIJAS: SISTEMĀTISKS PĀRSKATS PAR PSIHISKĀM IZPAUSMĒM AKŪTĀ PERIODĀ UN ILGTERMIN̦Ā UN AR TO SAISTİTĀM SMADZEN̦U IZMAIN̦ĀM}

Smags akūts respiratorā sindroma koronavīruss 2 (SARS-CoV-2) galvenokārt ietekmē elpošanas traktu, bet dažreiz arī citus orgānus, tostarp centrālo nervu sistēmu (CNS). Nav īsti skaidrs, kā vīruss ietekmē CNS un cik bieži tas notiek. Pārskats sniedz ieskatu par garīgo traucējumu rašanos ar koronovīrusu (COVID-19) inficētiem pacientiem. Apkopota informācija par smadzeņu šūnu jutīgumu pret SARS-CoV-2 bioloğisko pamatu un tā ietekmi uz psihiatriskām izpausmēm. Pārskatā iekḷautas 24 publikācijas, kurās ziṇots par psihiatriskām izpausmēm, tās publicētas laikā no 2019. gada 31. decembra līdz 2020. gada 30. jūlijam. Izmantota PRISMA pieeja (Preferred Reporting Items for Systemic Review and Meta-Analysis). Infekcijas akūtajā fāzē garīgie traucējumi radās līdz pat piektajai daḷai pacientu. Izplatîtākie traucējumi bija trauksmes un garastāvokḷa spektra traucējumi (depresija), apziņas traucējumi, apjukums, delīijs un psihoze. Psihiatrisko izpausmju parādī̌sanās COVID-19 inficêtiem pacientiem. ne vienmēr notiek pēc elpošanas simptomu atklāšanās. Ilgtermiṇa izpausmes galvenokārt ir depresija un pēctraumatiskā stresa simptomi. Balstoties uz iegūtajiem datiem, var apgalvot, ka tieša CNS inficēšanās ar SARS-CoV-2 varētu būt atbildīga par novērotajiem faktiem. Lai turpinātu pētīt ilgtermiņa psihiatriskās izpausmes, jāveic randomizēti kontrolēti pētījumi. 